\title{
Influence of SARS-CoV-2 on the Mediating Effect of Entrepreneurial Passion in the Relationship between Entrepreneurial Self-Efficacy and Innovative Behavior
}

Submitted 12/11/21, 1st revision 13/12/21, 2nd revision 12/01/22, accepted 10/02/22

\author{
Diego Norena-Chavez ${ }^{1}$
}

\begin{abstract}
:
Purpose: This research evaluated the mediating effect of entrepreneurial passion in the relationship between entrepreneurial self-efficacy and innovative behavior in a SARS-CoV-2 period.

Design/Methodology/Approach: Partial least squares structural equation modeling (PLSSEM) was used in a sample of 358 textile entrepreneurs.

Findings: Results show a significant complementary mediation effect of entrepreneurial passion on the relationship between entrepreneurial self-efficacy and innovative behavior. The model shows a moderate explanatory power with an $R^{2}$ of $36 \%$.

Practical Implications: This finding is important for further understanding the indirect and direct causes of innovative behavior and the interrelationship between the variables. Finally, this research helps understand innovative behavior in a developing country during a SARSCoV-2 period.

Originality/Value: A similar research was conducted before SARS-CoV-2. There is no research in the world, on the author's knowledge, evaluating these relationships in a COVID-19 context. This study is the first to empirically examine the mediating effect of entrepreneurial passion in the relationship between entrepreneurial self-efficacy and innovative behavior in a pandemic environment. This is a good reason to consider this research innovative, original and of high value.
\end{abstract}

Keywords: Mediation effect, PLS-SEM, complementary effect, textile industry, emerging economy

JEL codes: M21.

Paper type: Research article.

\footnotetext{
${ }^{1}$ Dr., The Peruvian Navy's Professional Specialization School, ORCID: https://orcid.org/0000-0001-5292-2152 diego.norena@hotmail.com;
} 


\section{Introduction}

SARS-CoV-2 has changed the business dynamics in several industries worldwide thus, many entrepreneurs needed specific competencies to adapt (Sheth, 2020). In financial terms, many companies were affected by the pandemic, but those with leaders with specific competencies managed to survive (Donthu and Gustafsson, 2020). Academic literature has studied the effect of entrepreneurial self-efficacy, entrepreneurial passion, and innovative behavior, as these variables are indispensable for business sustainability (Norena-Chavez and Thalassinos, 2021; Norena-Chavez and Guevara, 2020). However, these variables have not been studied within a SARS-CoV-2 context in the world.

Along the same lines as Norena-Chavez and Guevara (2020), this research determined the mediating effect of entrepreneurial passion in the relationship between entrepreneurial self-efficacy and innovative behavior but added the SARSCoV-2 to a better understanding of the interrelationships between the variables in a pandemic context and a developing country. The research answered the following questions:

a) what is the relationship between entrepreneurial passion and innovative behavior;

b) what is the relationship between entrepreneurial self-efficacy and entrepreneurial passion;

c) what is the relationship between entrepreneurial self-efficacy and innovative behavior;

d) what is the mediating effect of entrepreneurial passion on the relationship between entrepreneurial self-efficacy and innovative behavior?

First, the findings contributed to strengthening the predictive and explanatory model created by Norena-Chavez and Guevara (2020) but adding the effect of SARV-CoV2 to have a real understanding of the impact of the pandemic on these variables broadly related to entrepreneurship. Second, the findings helped narrow the knowledge gap in mediating entrepreneurial passion between entrepreneurial selfefficacy and innovative behavior (Newman, Tse, Schwarz, and Nielsen, 2018). Third, they contributed theoretically to the academic literature and provided empirical evidence of the relationship of the proposed variables. Finally, they contributed to a better understanding of the interrelationships of the variables, which influences the impact of ventures.

\section{Literature Review}

\subsection{Entrepreneurial Self-Efficacy and Entrepreneurial Passion}

Liu et al. (2021) found that entrepreneurial self-efficacy increased in nascent entrepreneurs when entrepreneurial passion was stronger. Bignetti et al. (2021) 
concluded that gender, age, program completed, family background, and family income showed no significant differences when studied together with entrepreneurial self-efficacy and entrepreneurial passion. Norena-Chavez and Thalassinos (2021) concluded that entrepreneurial self-efficacy and passion are positively and significantly related to industrial footwear in a developing country.

On the other hand, Norena-Chavez and Guevara's (2020) research concluded that entrepreneurial passion and entrepreneurial self-efficacy are positively related in a textile industrial setting in a developing country. Li et al. (2020) studied the relationship between entrepreneurial passion and entrepreneurial self-efficacy in a student environment in China and concluded that both variables are positively and significantly related. Taifur et al. (2020) investigated the influence of entrepreneurial self-efficacy and entrepreneurial passion on resilience in a culinary environment of small and medium enterprises. They found that there is no significant relationship between entrepreneurial self-efficacy and resilience.

However, entrepreneurial passion and resilience are positively and significantly related, as are entrepreneurial self-efficacy and entrepreneurial passion.

\subsection{Entrepreneurial Self-Efficacy and Innovative Behavior}

Hong-Da et al. (2014) concluded that entrepreneurial self-efficacy mediates the relationship between innovative behavior and entrepreneurial leadership in the military. Meanwhile, Norena-Chavez and Guevara (2020) found a positive and significant relationship of entrepreneurial self-efficacy on innovative behavior in the textile industry in a developing country. In the research of Newman et al. (2018), it was concluded that there is a positive influence between creative self-efficacy, which is a variant closely related to entrepreneurial self-efficacy, and innovative behavior.

In the workplace, many types of research confirmed the positive relationship between entrepreneurial self-efficacy and innovative behavior in generating creative environments (Tierney and Farmer, 2011; Mielniczuk and Laguna, 2020; Hsu, Hou, and Fan, 2011; Ng and Lucianetti, 2016; Norena-Chavez, 2020 ). In research related to star-ups, a positive relationship between variables is also shown (Hmieleski and Corbett, 2008; Chen and Zhou, 2017).

\subsection{Entrepreneurial Passion-Innovative Behavior}

Norena-Chavez and Guevara (2020) concluded a positive and significant relationship between entrepreneurial passion and innovative behavior in textile business owners. This research was conducted before COVID-19. In addition, entrepreneurial passion is a mediator in the relationship between entrepreneurial self-efficacy and innovative behavior (Norena-Chavez and Guevara, 2020). On the other hand, when entrepreneurial self-efficacy, entrepreneurial passion, 
innovativeness as behavior were studied in large and small companies, a positive and significant relationship between the variables was determined. (Ahlin et al., 2014; Prihatsanti, 2018).

\subsection{Entrepreneurial Self-Efficacy-Entrepreneurial Passion-Innovative Behavior}

In the academic literature, Norena-Chavez and Guevara (2020) were the only ones to research the relationship between entrepreneurial self-efficacy and innovative behavior. They tested the complementary mediating effect of entrepreneurial passion on the relationship between entrepreneurial self-efficacy and innovative behavior. This research was conducted before SARS- CoV-2, so there is no research in the world evaluating these relationships in a COVID-19 context.

Based on this literature review, the following hypotheses were put forward:

H1: Entrepreneurial passion positively influences innovative behavior.

H2: Entrepreneurial self-efficacy positively influences entrepreneurial passion.

H3: Entrepreneurial self-efficacy positively influences innovative behavior.

H4: Entrepreneurial passion mediates the relationship between the entrepreneurial self-efficacy and the innovative behavior.

Figure 1 shows the hypotheses put forward in this research based on the literature review.

Figure 1. Model Hypothesis

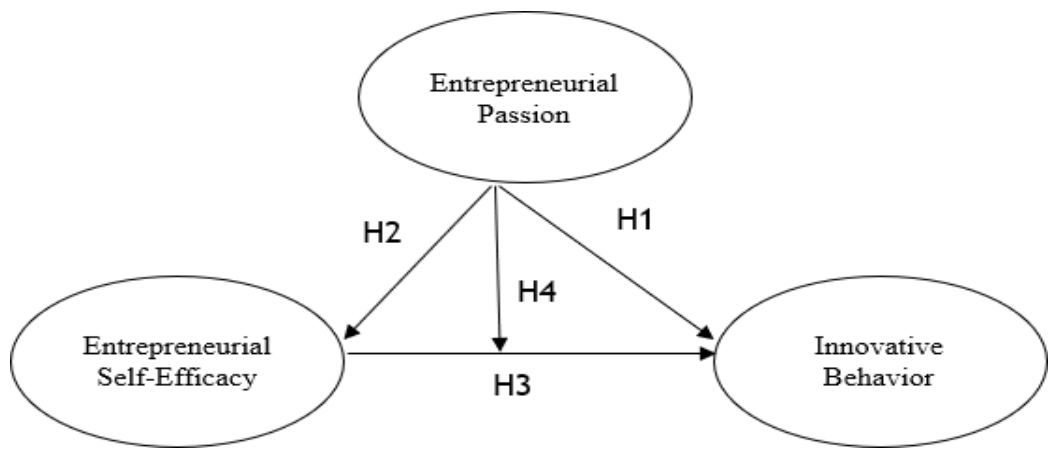

Source: Own study.

\section{Research Methodology}

The research design followed a quantitative methodological approach, crosssectional cohort, non-experimental design, correlational-explanatory scope, and followed post- positivist assumptions (Creswell, 2012). The analytical process followed the guideline proposed by Hair et al. (2019), as the research aimed to predict and explain relationships between variables. Partial Least Squares Structural 
Equation Modeling (PLS-SEM) was selected as the method of analysis (Hair et al., 2019; Chin, 2010; Henseler, Ringle, and Sinkovics, 2009; Hair, Ringle, and Sarstedt, 2011; Hair et al., 2014). Additionally, a theoretical framework was tested from a prediction perspective, and complexity was extended by testing established theories and given the existence of compounds within the estimated model.

According to Hair et al. (2017), PLS-SEM is recommended to assess the mediating effect, as it is based on the bootstrapping process. This makes no assumptions about the distribution of variables. The sample consisted of 358 textile entrepreneurs from the commercial emporium of Gamarra in La Victoria, Lima, Peru. To measure Entrepreneurial Passion, the scale of Cardon et al. (2013), consisting of 13 items and respondents to respond on a Likert scale ranging from $1=$ strongly disagree to $5=$ strongly agree, was used.

To measure entrepreneurial self-efficacy, DeNoble et al. (1999) scale was employed, consisting of 23 items and respondents to respond on a Likert scale ranging from $1=$ completely unable to $5=$ perfectly able. Scott and Bruce's (1994) scale was used to measuring innovative behavior, consisting of six items and respondents to respond on a Likert scale ranging from $1=$ not at all to $5=$ exceptional degree. Lastly, SmartPLS 3.3.3 software package was employed (Ringle et al. 2015) to evaluate all the reflective measurement models.

\section{Research Results}

This section is divided into the following parts: a) assessing reflective measurement model, and b) structural model assessment (Hair et al., 2019).

\subsection{Assessing Reflective Measurement Model}

The evaluation of the measurement model was conducted following the process developed by Hair et al. (2019) and consists of the following parts: a) individual indicator reliability, b) construct reliability, and c) discriminant validity.

\subsubsection{Individual Indicator Reliability}

According to Hair et al. (2019), those external loads with values less than 0.707 should be removed; however, before removal, there should be a prior evaluation. Figure 2 shows the research model and the external loads of the model meeting the criteria required by Hulland (1999). Figure 2 shows the measurement model and its external loads.

\subsubsection{Construct Reliability and Convergent Validity}

For construct reliability analysis, the following criteria were used: a) Cronbach's Alpha; b) composite reliability; and c) rho_A. According to Cronbach's (1951) criteria, Cronbach's Alpha indicator must be above the threshold of 0.7 for internal consistency to exist. Additionally, the composite reliability criterion was used to 
evaluate internal consistency, which, according to Jöreskog (1971), must be above the 0.7 threshold for internal consistency to exist.

Figure 2. Research Model

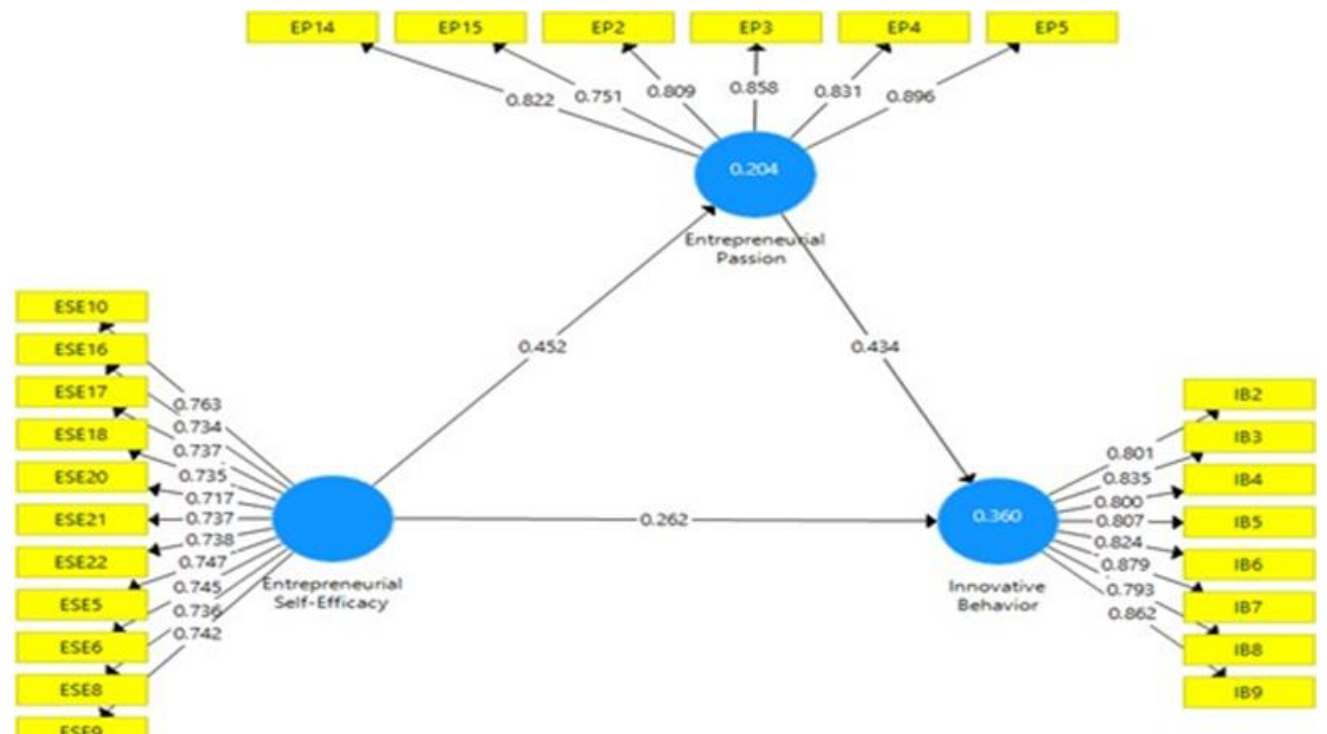

Note: Developed using version 3.3.3. of the SMART-PLS software (Ringle, Wide, and Becker, 2015).

On the other hand, the rho_A criterion was used to evaluate convergent validity, which must be above the threshold of 0.7 . Finally, to assess the convergent validity criterion, the average variance extracted (AVE) was employed, which must be above the threshold of 0.5 for convergent validity to exist (Hair et al., 2019). It is concluded that there is construct reliability and convergent validity, given that the values exceed the established thresholds of all criteria. Table 1 shows the reliability indicators.

Table 1. Construct Reliability

\begin{tabular}{|c|c|c|c|c|}
\hline Variable & $\begin{array}{l}\text { Cronbach's } \\
\text { Alpha }\end{array}$ & rho_A & $\begin{array}{l}\text { Composite } \\
\text { Reliability }\end{array}$ & $\begin{array}{l}\text { Av. Variance } \\
\text { Extracted } \\
\text { (AVE) }\end{array}$ \\
\hline Entrepreneurial Passion & 0.908 & 0.913 & 0.929 & 0.687 \\
\hline Entrepreneurial Self- & 0.917 & 0.920 & 0.930 & 0.546 \\
\hline \multicolumn{5}{|l|}{ Efficacy } \\
\hline Innovative Behavior & 0.933 & 0.938 & 0.945 & 0.682 \\
\hline
\end{tabular}
Becker, 2015). 


\subsubsection{Discriminant Validity}

The following criteria were used for discriminant validity assessment: a) Fornell and Larcker criteria, b) Cross Loadings, and c) HTMT. According to Fornell and Larcker (1981), for discriminant validity to exist, the square root of the AVE of a construct should be greater than the correlation it has with any other construct (Fornell and Larcker, 1981). Table 2 shows the variables and the corresponding values where Fornell and Larcker's criterion for discriminant validity is met.

Table 2. Fornell and Larcker Model

\begin{tabular}{|c|c|c|c|}
\hline Variable & EP & ESE & IB \\
\hline Entrepreneurial Passion (EP) & 0.829 & & \\
\hline $\begin{array}{l}\text { Entrepreneurial Self-Efficacy } \\
\text { (ESE) }\end{array}$ & 0.452 & 0.739 & \\
\hline Innovative Behavior (IB) & 0.552 & 0.458 & 0.82 \\
\hline
\end{tabular}

Note: Developed using version 3.3.3. of the SMART-PLS software (Ringle, Wide, and Becker, 2015).

After assessing the discriminant validity with Fornell and Larcker's (1981) criterion, the cross-loadings criterion was used. The external loadings of the indicators on their constructs should be greater than any of their cross-loadings (Hair et al., 2017). Table 3 shows the variables and their cross-loadings.

Table 3. Cross Loadings

\begin{tabular}{cccc}
\hline Variable & EP & ESE & IB \\
\hline EP14 & 0.822 & 0.336 & 0.436 \\
EP15 & 0.751 & 0.326 & 0.406 \\
EP2 & 0.809 & 0.358 & 0.443 \\
EP3 & 0.858 & 0.397 & 0.482 \\
EP4 & 0.831 & 0.401 & 0.465 \\
EP5 & 0.896 & 0.420 & 0.507 \\
ESE10 & 0.397 & 0.763 & 0.348 \\
ESE16 & 0.281 & 0.734 & 0.298 \\
ESE17 & 0.263 & 0.737 & 0.300 \\
ESE18 & 0.321 & 0.735 & 0.389 \\
ESE20 & 0.308 & 0.717 & 0.292 \\
ESE21 & 0.375 & 0.737 & 0.375 \\
ESE22 & 0.336 & 0.738 & 0.361 \\
ESE5 & 0.319 & 0.747 & 0.285 \\
ESE6 & 0.394 & 0.745 & 0.401 \\
ESE8 & 0.301 & 0.736 & 0.335 \\
ESE9 & 0.334 & 0.742 & 0.298 \\
IB2 & 0.425 & 0.362 & 0.801
\end{tabular}




$\begin{array}{llll}\text { IB3 } & 0.406 & 0.422 & 0.835 \\ \text { IB4 } & 0.404 & 0.400 & 0.800 \\ \text { IB5 } & 0.391 & 0.352 & 0.807 \\ \text { IB6 } & 0.502 & 0.392 & 0.824 \\ \text { IB7 } & 0.557 & 0.384 & 0.879 \\ \text { IB8 } & 0.391 & 0.332 & 0.793 \\ \text { IB9 } & 0.530 & 0.380 & 0.862\end{array}$

Note: Developed using version 3.3.3. of the SMART-PLS software (Ringle, Wide, and Becker, 2015).

Finally, to finish evaluating the discriminant validity, the HTMT criterion was used, which, according to Hair et al. (2019), represents the average of the heterotraithetero method correlations concerning the average of the monotrait-heteromethod correlations, and the HTMT criterion must be below the 0.85 threshold (Kline, 2011). Table 4 shows the HTMT of the variables.

Table 4. HTMT

\begin{tabular}{llll}
\hline Variable & EP & ESE & IB \\
\hline Entrepreneurial Passion & & & \\
Entrepreneurial Self- & & \\
Efficacy & 0.487 & \\
Innovative Behavior & 0.592 & 0.489 & \\
\hline
\end{tabular}

Note: Developed using version 3.3.3. of the SMART-PLS software (Ringle, Wide, and Becker, 2015).

\subsection{Assessing Structural Model}

For the evaluation of the structural model, the following analyses were employed: a) collinearity assessment, b) model path coefficients and evaluation of the model's, c) coefficient of determination ( $\mathrm{R}$ Square), d) effect size (F-Square), e) Q-Square predictive, and f) PLSpredict.

According to Hair et al. (2019), for collinearity to exist, the variance inflation factor (VIF) should be maximally in the range of 3-5. This is comparable with other previous research; the analysis shows that there isn't any problem with the collinearity of the model. Table 5 shows the collinearity indicators of the model.

Table 5. Collinearity Criterion Assessment

\begin{tabular}{cc}
\hline Variable & $\underline{\text { VIF }}$ \\
\hline EP14 & 2.459 \\
EP15 & 1.977 \\
EP2 & 2.114 \\
EP3 & 2.707 \\
EP4 & 2.503
\end{tabular}




\begin{tabular}{cc} 
EP5 & 3.381 \\
ESE10 & 2.099 \\
ESE16 & 2.165 \\
ESE17 & 2.271 \\
ESE18 & 1.944 \\
ESE20 & 1.824 \\
ESE21 & 1.940 \\
ESE22 & 1.943 \\
ESE5 & 2.083 \\
ESE6 & 1.968 \\
ESE8 & 2.060 \\
ESE9 & 2.132 \\
IB2 & 2.349 \\
IB3 & 2.756 \\
IB4 & 2.376 \\
IB5 & 2.377 \\
IB6 & 2.524 \\
IB7 & 3.588 \\
IB8 & 2.431 \\
IB9 & 3.295 \\
\hline
\end{tabular}

Note: Developed using version 3.3.3. of the SMART-PLS software (Ringle, Wide, and Becker, 2015).

\subsubsection{Assessment of Structural Model Path Coefficients and Evaluation of the Model's Mediation}

According to Hair et al. (2019), firstly, the symbols of the path coefficients should be compared with the symbols of the hypotheses proposed, where it was found that the signs of the coefficients and those of the hypotheses coincided. Secondly, the magnitude of the path coefficient should be evaluated, which should be in a range between -1 and 1 (Hair et al., 2021). Third, the significance of the path coefficients was assessed by bootstrapping at a $5 \%$ significance level and with 10,000 bootstrapping subsamples to test the significance of the paths (Streukens and LeroiWerelds, 2016). It was concluded that all three hypotheses are statistically significant. Table 6 shows the structural model path coefficients of the research.

Table 6. Structural Model Path Coefficients

\begin{tabular}{|c|c|c|c|c|c|c|c|}
\hline Variables & $\begin{array}{l}\text { Original } \\
\text { Sample }(O)\end{array}$ & $\begin{array}{l}\text { Sample } \\
(M)\end{array}$ & Mean & $\begin{array}{l}\text { Standard } \\
\text { Deviation } \\
(S T D E V)\end{array}$ & $\begin{array}{r}\text { T-Statistics } \\
(O / S T D E V)\end{array}$ & $\begin{array}{l}P \\
\text { Values }\end{array}$ & $\begin{array}{l}\text { Hypothesis } \\
\text { Supported? }\end{array}$ \\
\hline$E P \rightarrow I B$ & 0.434 & 0.436 & & 0.054 & 8.025 & 0.000 & Yes \\
\hline$E S E->E P$ & 0.452 & 0.456 & & 0.037 & 12.254 & 0.000 & Yes \\
\hline$E S E->I B$ & 0.262 & 0.262 & & 0.052 & 5.077 & 0.000 & Yes \\
\hline
\end{tabular}

Note: Developed using version 3.3.3. of the SMART-PLS software (Ringle, Wide, and Becker, 2015). 
To evaluate the mediating effect, the total indirect effect was analyzed by applying the bootstrapping technique. The indirect relationship was statistically significant, so the mediation hypothesis was tested. Table 7 shows the model indirect effect.

Table 7. Model Indirect Effect

\begin{tabular}{lcllccc}
\hline Variables & $\begin{array}{c}\text { Original Sample } \\
(\mathrm{O})\end{array}$ & $\begin{array}{l}\text { Sample } \\
\text { Mean(M) }\end{array}$ & $\begin{array}{c}\text { Standard } \\
\text { Deviation } \\
\text { (STDEV) }\end{array}$ & $\begin{array}{c}\text { T Statistics } \\
(\mathrm{O} / \mathrm{STDEV})\end{array}$ & P Values & $\begin{array}{c}\text { Hypothesis } \\
\text { Supported? }\end{array}$ \\
\hline $\begin{array}{l}\text { EP }>\text { IB } \\
\text { ESE->EP }\end{array}$ & & & & & & \\
ESE->IB & 0.196 & 0.199 & 0.032 & 6.121 & 0.000 & Yes \\
\hline
\end{tabular}

Note: Developed using version 3.3.3. of the SMART-PLS software (Ringle, Wide, and Becker, 2015).

Finally, the type of mediation was determined. The total effects were evaluated and compared with the indirect effects; both cases were positive and significant. According to Hair et al. (2019), it is concluded that there is complementary mediation. Table 8 shows the total effects of the structural model.

Table 8. Total Effects

\begin{tabular}{llllrll}
\hline & $\begin{array}{l}\text { Original } \\
\text { Sample(O) }\end{array}$ & $\begin{array}{l}\text { Sample } \\
\text { Mean }(\mathrm{M})\end{array}$ & $\begin{array}{l}\text { Standard } \\
\text { Deviation } \\
\text { (STDEV) }\end{array}$ & $\begin{array}{l}\text { T Statistics } \\
((\mid \mathrm{O} / \mathrm{STDEV})\end{array}$ & P Values & $\begin{array}{l}\text { Hypothesis } \\
\text { Supported? }\end{array}$ \\
\hline EP->IB & 0.434 & 0.434 & 0.0053 & 8.108 & 0.000 & Yes \\
ESE->EP & 0.452 & 0.456 & 0.037 & 12.158 & 0.000 & Yes \\
ESE->IB & 0.458 & 0.462 & 0.045 & 10.293 & 0.000 & Yes \\
\hline
\end{tabular}

Note: Developed using version 3.3.3. of the SMART-PLS software (Ringle, Wide, and Becker, 2015).

\subsubsection{Coefficient of Determination (R Square)}

The coefficient of determination indicates the amount of variance of a construct explained by the predictor variables of that endogenous construct in the model (Hair et al., 2019). In this model, the $\mathrm{R}^{2}$ has a value of 0.36 , which is a moderate level of explanatory power, according to Hair et al. (2014). Table 9 shows the $\mathrm{R}^{2}$ of the model.

Table 9. Model $R^{2}$

Note: Own study.

\begin{tabular}{ll}
\hline & $\mathrm{R}$ Square \\
\hline Entrepreneurial Passion & 0.204 \\
Innovative Behavior & 0.360 \\
\hline
\end{tabular}

\subsubsection{Effect Size (F-Square)}

To evaluate the effect size, we analyzed the $\mathrm{F}^{2}$ which, according to Cohen (1988), assesses the degree to which an exogenous construct explains a given construct in terms of the $\mathrm{R}^{2}$. 
This model presents a moderate effect size, as it is in the range between 0.15 and 0.35 . Table 10 shows the model $\mathrm{F}^{2}$.

Table 10. Model Effect Size

\begin{tabular}{lccc} 
& $\begin{array}{c}\text { Entrepreneurial } \\
\text { Passion }\end{array}$ & $\begin{array}{c}\text { Entrepreneurial Self- } \\
\text { Efficacy }\end{array}$ & $\begin{array}{c}\text { Innovative } \\
\text { Behavior }\end{array}$ \\
\hline EP & & & 0.234 \\
ESE & 0.257 & & 0.085 \\
IB & &
\end{tabular}

\subsubsection{Q-Square}

The Stone-Geisser test $\left(\mathrm{Q}^{2}\right)$ is used as a criterion to measure the predictive relevance of reflective dependent constructs. To calculate $\mathrm{Q}^{2}$, the blindfolding technique was employed, which removes single points in the data matrix and imputes the removed points with the average estimating parameter model (Sarstedt et al., 2014).

The model presents a value of 0.25 , so the predictive relevance of the model is medium (Hair, Risher, Sarstedt, and Ringle, 2019). Table 11 shows the predictive relevance of the model.

Table 11. Predictive Relevance of the Model

\begin{tabular}{llll}
\hline Variable & SSO & SSE & Q $^{2}(=1-$ SSE/SSO) \\
\hline $\begin{array}{l}\text { Entrepreneurial } \\
\text { Passion }\end{array}$ & 2148.00 & 1856.29 & 0.14 \\
$\begin{array}{l}\text { Entrepreneurial } \\
\text { Self-Efficacy }\end{array}$ & 3938.00 & 3938.00 & \\
$\begin{array}{l}\text { Innovative } \\
\text { Behavior }\end{array}$ & 2864.00 & 2179.70 & 0.25 \\
\hline
\end{tabular}

Note: Own study.

\subsubsection{PLSpredict}

The model shows a high predictive power for innovative behavior in the following items: a) IB7, b) IB9, c) IB5, d) IB6, e) IB2, and f) IB4. It has positive $\mathrm{Q}^{2}$ predict and negative differences for RMSE and MAE. On the other hand, the model shows little predictive power for item IB3 and no predictive power for item IB8 (Hair et al., 2019).Table 12 shows the PLSpredict evaluation indicators of the model.

Table 12. PLSpredict Model

\begin{tabular}{lllllllll}
\hline \multirow{2}{*}{ Variable } & PLS & LM & & PLS & LM & \multicolumn{2}{c}{ PLS } & LM \\
\cline { 2 - 9 } & RMS & RMSE & (RMSE PLS- & MAE & MAE & (MAE PLS- & Q ${ }^{2}$ predict & Q $^{2}$ _predict \\
& E & & RMS LM) & & & MAE LM) & & \\
\hline IB7 & 1.119 & 1.121 & -0.001 & 0.879 & 0.880 & -0.001 & 0.139 & 0.137 \\
IB9 & 1.286 & 1.295 & -0.009 & 1.003 & 1.022 & -0.019 & 0.137 & 0.125 \\
IB5 & 1.371 & 1.382 & -0.012 & 1.100 & 1.102 & -0.002 & 0.118 & 0.102
\end{tabular}




\begin{tabular}{lllllllll} 
IB6 & 1.100 & 1.120 & -0.020 & 0.849 & 0.862 & -0.014 & 0.147 & 0.115 \\
IB3 & 1.350 & 1.358 & -0.008 & 1.075 & 1.069 & 0.006 & 0.170 & 0.160 \\
IB8 & 1.479 & 1.477 & 0.002 & 1.191 & 1.173 & 0.018 & 0.104 & 0.107 \\
IB2 & 1.361 & 1.384 & -0.023 & 1.096 & 1.105 & -0.010 & 0.124 & 0.095 \\
IB4 & 1.436 & 1.470 & -0.035 & 1.158 & 1.170 & -0.012 & 0.154 & 0.112 \\
\hline
\end{tabular}

Note: Own study.

\section{Discussion and Conclusions}

This study aimed to examine the mediating effect of entrepreneurial passion on the relationship between entrepreneurial self-efficacy and innovative behavior based on Norena-Chavez and Guevara (2020) research. However, the impact of SARS-CoV-2 was considered to generate the first pandemic research studying these variables.

Based on the results of this study, the direct and indirect relationships of the variables included in the model (ESE, EP, and IB) were found to be statistically significant. That is, hypotheses $\mathrm{H} 1, \mathrm{H} 2, \mathrm{H} 3$, and $\mathrm{H} 4$ were accepted.

The test of $\mathrm{H} 1$ suggests that entrepreneurial passion is significantly related to innovative behavior. This is supported by previous research in business (NorenaChavez and Guevara, 2020; Ahlin et al., 2014; Prihatsanti, 2018).

In the case of $\mathrm{H} 2$ (the relationship between entrepreneurial passion and entrepreneurial self-efficacy), they are in line with previous research, such as those of Liu et al. (2021), Bignetti et al. (2021), Norena-Chavez and Thalassinos (2021), Norena-Chavez and Guevara (2020), Taifur et al. (2020).

Hypothesis $\mathrm{H} 3$, which tested the relationship between entrepreneurial self-efficacy and innovative behavior, was consistent with previous studies (Hong-Da et al., 2014; Norena- Chavez and Guevara, 2020; Newman et al., 2018; Tierney and Farmer, 2011; Hsu, Hou, and Fan, 2011; Ng and Lucianetti, 2016; Norena-Chavez, 2020; Hmieleski and Corbett, 2008; Chen and Zhou, 2017).

Concerning $\mathrm{H} 4$, the complementary mediation of entrepreneurial passion in the relationship between entrepreneurial self-efficacy and innovative behavior was tested. This research follows the line of Norena-Chavez and Guevara (2020) but added the effect of SARS-CoV-2. The $\mathrm{R}^{2}$ of the model has the value of 0.36 compared to the research of Norena and Guevara (2020), which presented a coefficient of determination of 0.35 . This study is the first to empirically examine the mediating effect of entrepreneurial passion in the relationship between entrepreneurial self-efficacy and innovative behavior in a pandemic environment.

Among the contributions of this research, the most important are, all four research hypotheses were accepted. The three relationships tested - ESE and IB, ESE and EP, and EP and IB - were all statistically significant. 
Furthermore, the complementary mediating effect of EP in the relationship between ESE and IB was also statistically significant. This research proved a predictive and explanatory model that will serve future research to understand the interrelationships between the variables.

It is recommended that future research incorporate the entrepreneurial intention variable in the proposed relationship, that further research be conducted evaluating the post-pandemic effect, and that it be complemented by research with a qualitative approach to understanding the profile of entrepreneurs in this sector.

Finally, the study will help entrepreneurs better understand the competencies that generate business sustainability.

\section{References:}

Ahlin, B., Drnovšek, M., Hisrich, R.D. 2013. Entrepreneurs' creativity and firm innovation: the moderating role of entrepreneurial self-efficacy. Small Business Economics, 43(1), 101-117. https://doi.org/:10.1007/s11187-013-9531-7.

Bignetti, B., Santos, A.C., Hansen, P.B., Henriqson, E. 2021. The influence of entrepreneurial passion and creativity on entrepreneurial intentions. Revista de Administração Mackenzie, 22(2). https://doi.org/ 10.1590/16786971/ERAMR21008.

Cardon, M.S., Gregoire, D.A., Stevens, C.E., Patel, P.C. 2013. Measuring entrepreneurial passion: Conceptual foundations and scale validation. Journal of business venturing, 28(3), 373-396. https://doi.org/10.1016/j.jbusvent.2012.03.003.

Chen, Y., Zhou, X. 2017. Entrepreneurial self-efficacy and firms' innovation behavior: The negative mediating role of social capital. Social Behavior and Personality, 45, 15531562. https://doi.org/10.2224/sbp.6734.

Chin, W.W. 2010. How to write up and report PLS analyses. In: Handbook of partial least squares, 655-690. Springer, Berlin, Heidelberg.

Cohen, J. 1988. Statistical Power Analysis for the Behavioral Sciences. Lawrence Erlbaum Associates.

Creswell, J.W. 2012. Educational research: Planning, conducting, and evaluating quantitative and qualitative research (4th ed.). Boston, Pearson Education, Inc.

DeNoble, A., Jung, D., Ehrlich, S. 1999. Entrepreneurial self-efficacy: The development of a measure and its relationship to entrepreneurial action. In: P.D. Reynolds (Ed.). Frontiers of entrepreneurship research, 73-87. Stanford, CA., Center for Entrepreneurial Studies.

Donthu, N., Gustafsson, A. 2020. Effects of COVID-19 on business and research. Journal of Business Research, 117, 284-289. https://doi.org/10.1016/j.jbusres.2020.06.008.

Fornell, C., Larcker, D.F. 1981. Structural equation models with unobservable variables and measurement error: Algebra and statistics. https://doi.org/10.1177/002224378101800313.

Hair Jr, J.F., Ringle, C.M., Sarstedt, M. 2011. PLS-SEM: Indeed a silver bullet. Journal of Marketing theory and Practice, 19(2), 139-152. https://doi.org/10.2753/MTP10696679190202.

Hair Jr, J.F., Sarstedt, M., Hopkins, L., Kuppelwieser, V.G. 2014. Partial least squares structural equation modeling (PLS-SEM). European business review. 
Hair Jr, J.F., Hult, G.T.M., Ringle, C.M., Sarstedt, M. 2017. A primer on partial least squares structural equation modeling (PLS-SEM) (2nd ed.). Thousand Oaks, Sage.

Hair Jr, J.F., Black, W.C., Babin, B., Anderson, R.E., Tatham, R. 2019. Multivariate data analysis. Cengage.

Hair Jr, J.F., Hult, T., Ringle, C., Sarstedt, M., Castillo, J., Cepeda, G., Roldán, J. 2019. Manual de Partial Least Squares Structural Equation Modeling (PLS-SEM). United State Sage Publication Inc.

Hair Jr, J.F., Risher, J.J., Sarstedt, M., Ringle, C.M. 2019. When to use and how to report the results of PLS-SEM. European Business Review, 31(1), 2-24. https://doi.org/10.1108/EBR-11-2018-0203.

Henseler, J., Ringle, C.M., Sinkovics, R.R. 2009. The use de partial least squares path modeling in international marketing. Advances in International marketing, 20, $277-$ 320. https://doi.org/10.1108/S1474-7979(2009)0000020014.

Hmieleski, K.M., Corbett, A.C. 2008. The contrasting interaction effects of Improvisational behavior with entrepreneurial self-efficacy on new venture performance and entrepreneur work satisfaction. Journal of Business Venturing, 23, 482-496. https://doi.org/10.1016/j.jbusvent.2007.04.002.

Hong-Da, L., Vivian, C.C.H., Chin-Tien, H., Wu-Chen, F. 2014. Relationship between Entrepreneurial Leadership and Innovative Behavior: The Mediating Effect of Entrepreneurial Self Efficacy and the Moderating Effect of Openness to Experience and Extraversion. Information Technology Journal, 13(6), 1035. https://doi.org/ 10.3923/itj.2014.1035.1044.

Hsu, M.L.A., Hou, S.T., Fan, H.L. 2011. Creative self-efficacy and innovative behavior in a service setting: Optimism as a moderator. Journal of Creative Behavior, 45, 258 272. https://doi.org/10.1002/j.2162-6057.2011.tb01430.x.

Hulland, J. 1999. Use of partial least squares (PLS) in strategic management research: A review of four recent studies. Strategic management journal, 20(2), 195-204. https://doi.org/10.1002/(SICI)1097-0266(199902)20:2<195::AID-SMJ13>3.0.CO;27.

Jöreskog, K.G. 1971. Simultaneous factor analysis in several populations. Psychometrika, 36(4), 409-426. https://doi.org/10.1007/BF02291366.

Kline, R.B. 2011. Principles and practice of structural equation modeling. New York, Guilford.

Li, C., Murad, M., Shahzad, F., Khan, M.A.S., Ashraf, S.F., Dogbe, C.S.K. 2020. Entrepreneurial passion to entrepreneurial behavior: Role of entrepreneurial alertness, entrepreneurial self-efficacy and proactive personality. Frontiers in Psychology, 11, 1611. https://doi.org/ 10.3389/fpsyg.2020.01611.

Liu, Y., Wang, W., Yuan, P., Yuan, Y. 2021. Curvilinear relationship of entrepreneurial experience and entrepreneurial self-efficacy: Entrepreneurial passion as a moderator. Social Behavior and Personality: an international journal, 49(5), 1-15. https://doi.org/ 10.2224/sbp.10181.

Mielniczuk, E., Laguna, M. 2020. Positive affect mediates the relationship between self-efficacy and innovative behavior in entrepreneurs. The Journal of Creative Behavior, 54(2), 267-278. https://doi.org/10.1002/jocb.364.

Ng, T.W.H., Lucianetti, L. 2016. Within-individual increases in innovative behavior and creative, persuasion, and change self-efficacy over time: A social-cognitive theory perspective. Journal of Applied Psychology, 101, 14-34. https://doi.org/10.1037/ ap10000029.

Newman, A., Tse, H.H.M., Schwarz, G., Nielsen, I. 2018. The effects of employees' creative 
self-efficacy on innovative behavior: The role of entrepreneurial leadership. Journal of Business Research, 89, 1-9. https://doi.org/10.1016/j.jbusres.2018.04.001.

Norena-Chavez, D. 2020. The Mediation Effect of Innovative Behavior on the Relationship Between Entrepreneurial Self-Efficacy and Entrepreneurial Intention. International Journal of Economics and Business Administration, 8(4), 238-252. https://doi.org/ $10.35808 / \mathrm{ijeba} / 583$.

Norena-Chavez, D., Guevara, R. 2020. Entrepreneurial passion and self-efficacy as factors explaining innovative behavior: A mediation model. International Journal of Economics and Business Administration, 8(3), 352-373. https://doi.org/ $10.35808 / \mathrm{ijeba} / 522$.

Norena-Chavez, D., Thalassinos, E.I. 2021. The Mediation Effect of Entrepreneurial SelfEfficacy in the Relationship between Entrepreneurial Passion and Leadership Styles. Academy of Strategic Management Journal, 20(2), 1-9.

Prihatsanti, U. 2018. The Relationship Between Entrepreneurial Self-Efficacy, Entrepreneurial Curiosity and Innovative Behavior on Entrepreneur Students. Advances in Social Science, Education and Humanities Research, 133, 131-134. https://doi.org/10.2991/acpch-17.2018.31.

Ringle, C.M., Wende, S., Becker, J.M. 2015. SmartPLS 3. Bönningstedt: SmartPLS.

Sarstedt, M., Ringle, C.M., Henseler, J., Hair Jr, J.F. 2014. On the emancipation of PLSSEM: a commentary. In: Rigdon Long Range Planning, 47(4), 154-160.

Scott, S.G., Bruce, R.A. 1994. Determinants of innovative behavior: A path model of individual innovation in the workplace. Academy of management journal, 37(3), 580-607. https://doi.org/10.5465/256701.

Sheth, J. 2020. Business of business is more than business: managing during the Covid crisis. Industrial Marketing Management. https://doi.org/10.1016/j.indmarman.2020.05.08.

Streukens, S., Leroi-Werelds, S. 2016. Bootstrapping and PLS-SEM: A step-by-step guide to get more out of your bootstrap results. European Management Journal, 34(6), 618632. https://doi.org/10.1016/j.emj.2016.06.003.

Taifur, W.D., Rahman, H., Ridwan, E., Devianto, D. 2020. Entrepreneurial resilience: The role of entrepreneurial self-efficacy and entrepreneurial passion in disaster prone areas. International Journal of Entrepreneurship, 24(5), 1-11.

Tierney, P., Farmer, S.M. 2011. Creative self-efficacy development and creative performance over time. Journal of Applied Psychology, 96, 277-293. https://doi.org/10.1037/a002095. 